\title{
La Revolución mexicana en el cine
}

\section{Yolanda Maldonado}

México es un país que ha pasado por numerosos períodos cruciales durante toda su historia. Uno de esos momentos fue la Revolución mexicana, la cual marcó al país de diferentes maneras. Grupos de hombres y mujeres mexicanas, especialmente campesinos, emprendieron una lucha contra el gobierno porque estaban cansados de todas las injusticias a las que fueron sometidos por el gobierno. Gracias a la Revolución el país volvió a nacer para muchas personas y para otras este suceso nunca debió de haber ocurrido. A causa de todos los hechos que sucedieron en la Revolución la historia se convirtió en algo atractivo para el cine y especialmente para el mexicano. Siendo esto así, muchas películas relacionadas con la Revolución fueron filmadas por extranjeros y mexicanos que mostraron al público sus propias perspectivas. Algunas de estas películas son: ¡Que Viva México! (1932), El compadre Mendoza (1934), que critica la traición que existió durante la Revolución; Vámonos con Pancho Villa (1936), el cual juzga al caudillo revolucionario que demuestra símbolos únicos de los mexicanos; y por último Memorias de un mexicano (1950), que manifiesta un México fuerte.

Comparar detalladamente lo que las películas relatan es algo importante e interesante de hacer. Una de las películas que muestra símbolos del país es ¡Que Viva México!, la cual fue dirigida por el extranjero Sergei Einsenstein. En el filme, el director se encarga de mostrar símbolos que resaltan la identidad mexicana al igual que la cultura y las tradiciones del país. Algunos de estos símbolos fueron el de la Virgen de Guadalupe, la cual significa el mestizaje y el catolicismo mexicano. Además, se hace presente el maguey, que es un símbolo que representa las injusticias a las que los campesinos eran sometidos por los hacendados refiriéndose al periodo del porfiriato. Esta película llega a la conclusión que México es un país lleno símbolos que lo convierten en una nación única.

La producción cinematográfica mexicana logró destacarse gracias al gran trabajo que realizaron muchos directores. Fernando de Fuentes ha sido uno de los mejores y de los más destacados e importantes en la historia del cine. Él implantó cosas nuevas al cine que antes nadie había hecho en las producciones del cine de guerra. Gracias a sus producciones a este periodo se le consideró como el Cine de Oro. La película El compadre Mendoza relata cómo en la Revolución hubieron hacendados que traicionaban a las fuerzas gubernamentales y al ejército de Zapata. Esta película hace una crítica fuerte sobre las traiciones que sucedieron en el transcurso de la Revolución y revela al espectador que existieron hacendados que se 
cambiaban de ejércitos según su conveniencia. La película es controvertida debido a que esta parte de la historia no se ha situado en los libros de texto de historia del país.

Otras de las películas importantes de De Fuentes es Vámonos con Pancho Villa, en la cual la historia hace críticas fuertes sobre el caudillo Villa. La película comienza con pensamientos y actitudes positivas de un grupo de campesinos que se unen al ejército de Villa, pero poco a poco esas actitudes se van perdiendo conforme van conociendo quién en realidad es Villa. El director demuestra cómo muchos campesinos al inicio de la Revolución mexicana sentían ganas de luchar por sus derechos y no les importaba dejar sus familias por seguir al caudillo Villa. Por medio de esta historia el director permite percibir al espectador que para los campesinos no fue fácil luchar contra el gobierno y aún menos cuando el caudillo Villa era un oportunista que sólo veía por su bienestar y no por el de su ejército.

Otra de las películas más significativas para el cine mexicano es Memorias de un Mexicano de Salvador Toscano. El gran objetivo de la película es demostrar al pueblo que todo lo que ha sucedido en la Revolución mexicana ha sido por el bien de la nación. Es una serie de noticieros que narran el movimiento de la Revolución intentando exaltar los logros del gobierno. Los directores aprovecharon los beneficios del cine y vieron bien filmar para educar al pueblo y para mostrar un país fuerte. La película va creando en el espectador un sentido coherente de todos los sucesos del movimiento. Esta es una propaganda que se centra en divulgar el progreso de los gobiernos después de la Revolución. Al final de la película el espectador queda con la impresión de que el gobierno mexicano siempre actúa por el bien del pueblo.

La historia de la Revolución mexicana cuenta con muchos puntos importantes, por lo que filmarla logra ser algo atractivo para los directores del cine. Ciertamente, cada una de estas películas tiene sus propias perspectivas puesto que cada director analiza la historia de diferentes maneras. Todas estas películas que menciono permiten al espectador admirar símbolos, cultura y tradiciones que nos permiten formar nuestra propia crítica sobre la Revolución mexicana. 